\title{
Penerapan Model Vector Autoregressive Integrate Moving Average dalam Peramalan Laju Inflasi dan Suku Bunga di Indonesia
}

\author{
Jusmawati $^{a, *}$, Mustika Hadijati $^{b}$, Nurul Fitriyani ${ }^{c}$ \\ a,* Program Studi Matematika, FMIPA, Universitas Mataram, J1 Majapahit No. 62, Mataram, 83125, Indonesia. \\ Email: Jusmawati655@g mail.com \\ ${ }^{b}$ Program Studi Matematika, FMIPA, Universitas Mataram, J1 Majapahit No. 62, Mataram, 83125, Indonesia. Email: \\ mustika.hadijati@unram.ac.id \\ ${ }^{c}$ Program Studi Matematika, FMIPA, Universitas Mataram, J1 Majapahit No. 62, Mataram, 83125, Indonesia. Email: \\ nurul.fitriyani@unram.ac.id
}

\section{A B S T R A C T}

The inflation and interest rates in Indonesia have a significant impact on the country's economic development. Indonesian inflation and interest rates data are multivariate time series data that show activity over a certain period of time. Vector Autoregressive Integrated Moving Average (VARIMA) is a method for analyzing multivariate time series data. This method is a simultaneous equation modeling that has several endogenous variables simultaneously. This study aimed to model the inflation and interest rates data, from January 2009 to December 2016 and predict inflation and interest rates by using VARIMA method. The model obtained was the VARIMA $(0,2,2)$ model, with estimated parameters using the maximum likelihood method. The choice of the VARIMA $(0,2,2)$ model was based on the smallest AIC value of -4,2891, with a MAPE value for the inflation and interest rates forecasting were 6,04\% and $1,84 \%$, respectively, which ind icates a very good forecast results.

Keywor ds: A kaike's Information Criterion (AIC); Mean Abs olute Percentage Error (MAPE); Multivariate time series; VA RIMA.

\section{A B S T R A K}

Laju inflasi dan suku bunga Indonesia memiliki dampak yang cukup besar bagi perkembangan perekonomian negara. Data laju inflasi dan suku bunga Indonesia merupakan data runtun waktu multivariat yang menunjukkan aktivitas selama kurun waktu tertentu. Salah satu metode untuk menganalis is data ini adalah Vector Autoregressive Integrated Moving Average (VARIMA). Metode ini merupakan pemodelan persamaan simultan yang memiliki beberapa variabel endogen secara bersamaan. Penelitian ini bertujuan untuk memodelkan data laju inflasi dan suku bunga periode Januari 2009 sampai dengan Desember 2016, serta meramalkan kedua data runtun waktu dengan menggunakan metode VARIMA. Model yang diperoleh adalah model VARIMA(0,2,2), dengan estimasi parameter

* Corresponding author.

Alamat e-mail: Jusmawati655@gmail.com 
menggunakan metode maximum likelihood. Pemilihan model VARIMA $(0,2,2)$ didasarkan pada nilai AIC terkecil sebesar $-4,2891$, dengan nilai MAPE masing-masing untuk peramalan laju inflasi dan suku bunga masing-masing sebesar $6,04 \%$ dan $1,84 \%$, yang mengindikasikan hasil peramalan yang sangat baik.

Kata Kunci: Akaike's Information Criterion (AIC); Mean Absolute Percentage Error (MAPE); Time series multivariat; VARIMA.

\section{Pendahuluan}

Dalam suatu negara, inflasi sangat mempengaruhi stabilitas perekonomian negara tersebut karena laju inflasi yang tinggi mempengaruhi tingkat produksi dalam negeri, melemahkan produksi barang ekspor. Laju inflasi yang tinggi dapat menurunkan produksi, karena harga menjadi tinggi dan permintaan akan barang menurun. Pada prinsipnya, tidak semua inflasi berdampak negatif pada perekonomian. Terutama jika terjadi inflasi ringan, yaitu inflasi di bawah $10 \%$. Inflasi ringan justru dapat mendorong terjadinya pertumbuhan ekonomi. Hal ini karena inflasi mampu memberi semangat kepada pengusaha, untuk lebih meningkatkan produksinya dengan membuka lapangan kerja baru. Salah satu faktor penentu pertumbuhan ekonomi yang lainnya adalah suku bunga (Sukirno, 2008).

Menurut Sunariyah (2014), suku bunga merupakan salah satu variabel dalam perekonomian yang senantiasa diamati secara cermat karena dampaknya yang luas. Suku bunga mempengaruhi secara langsung kehidupan masyarakat keseharian dan mempunyai dampak penting terhadap kesehatan perekonomian, serta biasa diekspresikan sebagai persentase pertahun yang dibebankan atas uang yang dipinjam. Tingkat bunga pada hakikatnya adalah harga. Kenaikan atau penurunan tingkat suku bunga Bank Indonesia (BI-rate) akan mempengaruhi tingkat suku bunga antar bank dan tingkat suku bunga deposito yang berakibat pada perubahan suku bunga kredit. Hal ini menyebabkan laju inflasi dan suku bungan memiliki dampak yang cukup besar bagi perkembangan perekonomian negara. Oleh karenanya, peran pemerintah dalam merencanakan, mengambil serta mengevaluasi kebijakan perekonomian yang dapat mempengaruhi hal-hal tersebut sangat diperlukan, sehingga perlu dilakukan peramalan terhadap nilai laju inflasi dan suku bunga.

Analisis time series merupakan metode yang mempelajari deret waktu, baik dari segi teori maupun untuk membuat peramalan (prediksi). Analisis ini merupakan cara menentukan variabilitas data time series. Analisis in i pada dasarnya digunakan untuk melakukan analisis data yang mempertimbangkan pengaruh waktu. Data yang digunakan dapat bersifat deterministik, non-determin istik atau data acak, yang biasanya dikumpulkan secara periodik berdasarkan urutan waktu dalam jam, hari, minggu, bulan, kuartal,atau tahun. Analisis ini tidak hanya dapat dilakukan untuk data yang me miliki satu variabel saja tetapi juga bisa untuk data yang memiliki banyak variabel (Makridakis, dkk., 1999).

Terdapat berbagai macam metode untuk menganalis is data time series, baik univariat maupun multivariat. Metode yang dapat digunakan dalam analisis data time series univariat salah satunya Autoregressive Integrated Moving Average(ARIMA) sedangkan dalam menganalisis data time seriesmultivariat, dapat digunakan metode VARMA, VARIMA, VARIMAX, GSTAR, dan VECM. Oleh karena data time series ekonometrika lebih dominan bersifat tidak stasioner, maka metode yang cocok digunakan untuk meramalkan data tersebut adalah metode Vector Autoregressive Integrated Moving Average atau VARIMA (Rinaldy, 2016).

Model VARIMA merupakan pengembangan dari model ARIMA yang digunakan untuk menganalisis data time series univariat. Model ini merupakan bentuk vektor dari model ARIMA, sehingga dalam aplikasinya diperlukan data-data yang telah stasioner dan memiliki keterhubungan antara masing-masing variabel. Model ini juga memiliki kelebihan yaitu meramalkan data time series multivariat yang terdiri atas variabel-variabel endogen yang bersifat stokastik, dimana variabel endogen tersebut dalam suatu persamaan simultan memiliki kemungkinan akan muncul sebagai variabel eksogen pada persamaan lain (Wei, 2006).

\section{Landasan Teori}

\subsection{Stasioneritas}

Suatu proses dikatakan stasioner jika dalam proses tersebut tidak terdapat perubahan kecenderungan baik dalam rata-rata maupun nilai varian yang saling konstan (Makridakis, dkk., 1999). Data yang belum memenuhi kondisi stasioner terhadap varian dapat diatasi dengan menggunakan transformasi Box-Cox dengan rumus sebagai berikut (Wei, 2006) ;

$$
T\left(Z_{t}\right)=\frac{Z_{t}^{(\lambda)}-1}{\lambda}
$$

dengan,

$Z_{t}$ : nilai variabel pada waktu ke- $t$ 
$\lambda$ : parameter transformasi.

Transformasi Box-Cox dilakukan untuk mengatasi ketidakstasioneran data terhadap varian tergantung pada nilai lambda $(\lambda)$ yang dimiliki. Pada Tabel 1 berikut diberikan transformasi yang harus dilakukan apabila data yang dianalisis memiliki nilai la mbda $(\lambda)$ tertentu.

\begin{tabular}{cc}
\multicolumn{2}{c}{ Tabel 1 - Transfor masi Box-Cox } \\
\hline Nilai $\lambda$ & Transformasi \\
\hline-1 & $1 / Z_{t}$ \\
$-0,5$ & $1 / \sqrt{Z_{t}}$ \\
0 & $\ln \left(Z_{t}\right)$ \\
0,5 & $\sqrt{Z_{t}}$ \\
1 & $Z_{t}$ (tanpa transformasi) \\
\hline Sumber : (Wei, 2006)
\end{tabular}

Selanjutnya, ketika data tidak menunjukkan ratarata yang konstan, biasanya dapat dibuat data baru dengan melakukan differencing (pembedaan) pada data, yaitu dengan menghitung perubahan berturutturut pada data untuk semua $t$, sebagai berikut:

$$
w_{t}=z_{t}-z_{t-1}
$$

dengan,

$w_{t}:$ data hasil differencing

$z_{t}$ : nilai variabel pada waktu ke- $t$

$z_{t-1}$ : nilai variabel pada waktu ke- $(t-1)$.

\subsection{Matrix Autocorrelation Function (MACF)}

Jika terdapat sebuah vektor time series dengan pengamatan sebanyak $n$, yaitu $Z_{1}, Z_{2}, \ldots, Z_{n}$ maka persamaan matriks korelasi sampelnya adalah sebagai berikut.

$$
\hat{\rho}(k)=\left\lfloor\hat{\rho}_{i j}(k)\right\rfloor
$$

dengan $\hat{\rho}_{i j}(k)$ merupakan korelasi silang sampel untuk komponen data ke- $i$ dan ke- $j$ yang dinyatakan dalam persamaan berikut.

$$
\begin{gathered}
\hat{\rho}_{i j}(k)=\frac{\sum_{t=1}^{n-k}\left(Z_{i, t}-\bar{Z}_{i}\right)\left(Z_{j, t+k}-\bar{Z}_{j}\right)}{\left[\sum_{t=1}^{n}\left(Z_{i, t}-\bar{Z}_{i}\right)^{2} \sum_{t=1}^{n}\left(Z_{j, t}-\bar{Z}_{j}\right)^{2}\right]^{1 / 2}} \\
\bar{Z}_{i} \text { dan } \bar{Z}_{j} \text { merupakan rata-rata sampel dari }
\end{gathered}
$$

ko mponen deret yang bersesuaian (Wei, 2006).

\subsection{Matrix Partial Autocorrelation Function (MPACF)}

Matriks fungsi autokorelasi parsial pada lag $s$, dilambangkan dengan $\mathrm{P}(s)$, fungsi matriks autokorelasi parsial didapatkan berdasarkan persamaan Yule-Walker sebagai berikut (Wei, 2006):

$$
\begin{aligned}
& {\left[\begin{array}{cccc}
\Gamma(0) & \Gamma^{\prime}(1) & \cdots & \Gamma^{\prime}(s-1) \\
\Gamma(1) & \Gamma(0) & \cdots & \Gamma^{\prime}(s-2) \\
\vdots & \vdots & \ddots & \vdots \\
\Gamma(s-1) & \Gamma(s-2) & \cdots & \Gamma(0)
\end{array}\right]_{s \times s}} \\
& {\left[\begin{array}{c}
\Phi_{s, 1}^{\prime} \\
\Phi_{s, 2}^{\prime} \\
\vdots \\
\Phi_{s, s}^{\prime}
\end{array}\right]_{s \times 1}=\left[\begin{array}{c}
\Gamma(1) \\
\Gamma(2) \\
\vdots \\
\Gamma(s)
\end{array}\right]_{s \times 1}}
\end{aligned}
$$

dengan,

$$
\begin{aligned}
\Gamma(s) & =E\left(Z_{t} Z_{t+s}^{\prime}\right) \\
\Phi_{s \times s} & =\left[\begin{array}{ccc}
\Phi_{s \times s, 11} & \cdots & \Phi_{s, s, 1 m} \\
\vdots & \ddots & \vdots \\
\Phi_{s, d, m 1} & \cdots & \Phi_{s, s, m m}
\end{array}\right]
\end{aligned}
$$

Keterangan:

$\Gamma(s)$ : matriks kovarian lag ke-s berukuran $m \times m$ $\Phi_{s \times s}$ : parameter vector Autoregressive.

\subsection{Akaike's Information Criterion (AIC)}

Kriteria Akaike's Information Criterion (AIC) dapat diru muskan sebagai berikut (Hermayani, dkk., 2014):

$$
\operatorname{AIC}_{(p, q)}=\ln |\Sigma|+\frac{2 k^{2}(p+q)}{T}
$$

dengan,

$\ln :$ logarit ma natural

$T$ : banyaknya pengamatan

$k$ : banyaknya variabel dalam model

$p:$ orde AR

$q$ : ordeMA

$\Sigma:$ matriks kovarian residual

\subsection{Maximum Likelihood Estimation (MLE)}

Misalkan $X$ variabel acak berdistribusi normal dengan rata-rata $\mu$ dan varian $\sigma^{2}$ ditulis $X \sim N\left(\mu, \sigma^{2}\right)$. Fungsi kepadatan peluang dari $X$ 
didefinisikan sebagai berikut (Matjik dan Sumertajaya, 2011).

$$
\begin{aligned}
f(x)= & \frac{1}{\sigma \sqrt{2 \pi}} \exp \left\{-\frac{1}{2}\left(\frac{x-\mu}{\sigma}\right)^{2}\right\} \\
& -\infty<x<\infty,-\infty<\mu<\infty, \quad \sigma>0
\end{aligned}
$$

Apabila $X_{1}, X_{2}, \ldots, X_{p}$ adalah variabel acak berdistribusi normal dan saling independen, dengan rata-rata $\mu_{i}$ dan varian $\sigma_{i}{ }^{2}$, maka fungsi densitas bersama diberikan sebagai berikut.

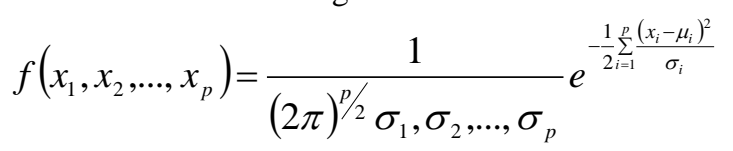

Misalkan $X_{1}, X_{2}, \ldots, X_{p}$ adalah sampel acak dari populasi dengan densitas $f\left(X_{t} ; \vartheta\right)$, maka fungsi likelihood didefinisikan:

$$
L\left(\vartheta_{1}, \vartheta_{2}, \ldots, \vartheta_{n}\right)=\prod_{t=1}^{T} f\left(X_{t} ; \vartheta\right)
$$

Apabila fungsi likelihood ini terdiferensialkan, maka estimator likelihood yang mungkin adalah :

$$
\frac{\partial L(\vartheta)}{\partial \vartheta}=0
$$

Untuk membuktikan bahwa $\vartheta$ benar-benar memaksimumkan fungsi likelihood $L(\vartheta)$ harus ditunjukkan bahwa :

$$
\frac{\partial^{2} L(\vartheta)}{\partial \vartheta^{2}}<0
$$

Dalam banyak kasus dimana diferensi digunakan, akan lebih mudah bekerja pada logaritma dari $L(\vartheta)$ yaitu $\log L(\vartheta)$. Hal ini dimungkinkan karena fungsi logaritma monoton naik pada $(0, \propto)$. Dengan demikian, estimator maximum likelihood dari $\vartheta$ diperoleh dengan menentukan turunan dari $L_{t}=\log L(\vartheta)$ terhadap $\vartheta$. Penyelesaian dari persamaaan $L_{t}=\log L(\vartheta)$ merupakan estimator maximum likelihood untuk parameter $\vartheta$ (Bain dan Engelhardt, 1992).

\subsection{Pengujian Signifikansi Parameter}

Pengujian signifikansi parameter dilakukan untuk menguji nilai kelayakan estimasi parameter untuk masuk kedalam model.Statistik uji yang digunakan adalah statistik uji dengan menggunakan distribusi $t$ dengan persamaan model Vector Autoregressive (VAR) sebagai berikut.

$$
t_{\text {hitung }}=\frac{\hat{\phi}_{i j}^{l}}{S E\left(\hat{\phi}_{i j}^{l}\right)}
$$

Selanjutnya, diberikan model Vector Moving Average (VMA) sebagai berikut.

$$
t_{\text {hitung }}=\frac{\hat{\theta}_{i j}^{l}}{S E\left(\hat{\theta}_{i j}^{l}\right)}
$$

Keterangan:

$\hat{\phi}_{i j}^{l}:$ nilai taksiran dari parameter $\phi$

$\hat{\theta}_{i j}^{l}:$ nilai taksiran parameter $\theta$

$\operatorname{SE}\left(\hat{\phi}_{i j}^{l}\right):$ standarerror dari nilai taksiran $\hat{\phi}$

$\operatorname{SE}\left(\hat{\theta}_{i j}^{l}\right):$ standar error dari nilai taksiran $\hat{\theta}$

Apabila ditetapkan taraf signifikan $\alpha$, maka daerah penolakannya adalah tolak dugaan awal bahwa parameter tidak signifikan apabila diperoleh $\left|t_{\text {hitung }}\right|>t_{\alpha / 2 ; d f,(n-p-1)}$ atau $p$-value $<\alpha$, dengan $n$ banyaknya pengamatan dengan $k$ adalah banyaknya parameter (Wei, 2006).

\subsection{Pengujian Residual}

Pengujian residual pertama yang dilakukan dalam analisis runtun waktu adalah pengujian white noise. Statistik uji untuk multivariat yang digunakan adalah statistik uji Ljung Box-Pierce dengan persamaan sebagai berikut :

$$
Q_{k}(m)=T^{2} \sum_{l=1}^{m} \frac{1}{T-1} \operatorname{tr}\left(\widehat{\Gamma}_{l}^{\prime \prime} \widehat{\Gamma}_{0}^{-1} \widehat{\Gamma}_{l} \widehat{\Gamma}_{0}^{-1}\right)
$$

dengan,

$T$ : banyaknya data

$m$ : banyaknya lag yang diuji

$\hat{\Gamma}_{l}$ : estimasi autokorelasi residual periode $m$

tr : penjumlahan diagonal utama.

Kriteria pengambilan keputusan yaitu menerima dugaan awal bahwa data bersifat white noise apabila $Q_{k}(m)<\chi^{2}$ atau $p$-value $>\alpha$, yang artinya residual memenuhi syarat white noise dan menunjukkan bahwa barisan error tidak memiliki autokorelasi (Wei, 2006).

Selanjutnya, dilakukan pengujian normalitas residual. Uji Kolmogorov-Smirnov merupakan uji kenormalan yang populer, didasarkan pada nilai D yang didefinisikan sebagai berikut:

$$
D=S U P_{x}\left\lfloor\mid F(x)-F_{0}(x) \|\right.
$$

dengan, 
$F(x)$ : fungsi peluang kumulatif data sampel

$F_{0}(x)$ : fungsi peluang kumulatif distribusi normal

Apabila ditetapkan taraf signifikan $\alpha$, maka daerah penolakannya adalah tolak dugaan awal bahwa data berdistribusi normal apabila $D>D(1-\alpha, n)$ atau $p$ value $<\alpha$, dengan $n$ merupakan banyaknya data atau observasi (Draper dan Smith, 1998).

\subsection{Mean Absolute Percentace Error (MAPE)}

Tahapan akhir dalam analisis adalah melakukan peramalan dengan menggunakan model terbaik yang telah memenuhi asumsi residual. Selanjutnya, dilakukan evaluasi untuk mengukur kesalahan nilai estimasi model menggunakan kriteria Mean Absolute Percentage Error (MAPE).Persamaan MAPE yang digunakan antara lain sebagai berikut.

$$
\text { MAPE }=\frac{1}{n} \sum_{t-1}^{n}\left|\frac{X_{t}-F_{t}}{X_{t}}\right| \times 100 \%
$$

dengan,

$X_{t}$ : data aktual periode ke- $t$

$F_{t}$ : peramalan periode ke- $t$

$n$ : banyaknya data.

Suatu model mempunyai kinerja sangat baik jika nilai MAPE berada di bawah $10 \%$, dan mempunyai kinerja baik apabila nilai MAPE berada di antara 10\% dan 20\% (Zainun dan Majid, 2003).

\subsection{Model Vector Autoregressive Integrated Moving Average (VARIMA)}

Secara umum bentuk model VARIMA diberikan sebagai berikut (Wei, 2006).

$$
\phi_{p}(B) D(B) Y_{t}=\theta_{q}(B) \alpha_{t}
$$

dengan,

$$
\begin{aligned}
& \phi_{p}(B)=\phi_{0}-\phi_{1} B-\phi_{2} B^{2}-\ldots-\phi_{p} B^{p} \\
& \theta_{q}(B)=\theta_{0}-\theta_{1} B-\theta_{2} B^{2}-\ldots-\theta_{q} B^{q} \\
& \phi_{0}=\theta_{0}=1 \\
& B Z_{t}=Z_{t-1} \\
& B a_{t}=a_{t-1} \\
& Y_{t}=\left[Y_{1, t}, Y_{2, t}, \ldots, Y_{n, t}\right]^{\prime}
\end{aligned}
$$

$Y_{t}$ merupakan vektor time series multivariat yang terkoreksi nilai rata-ratanya, $\phi_{p}(B) \operatorname{dan} \theta_{q}(B)$ berturut-turut adalah matriks autoregressive dan moving average polinomial orde $p$ dan $q$.
Keterangan:

$Y_{t}:$ vektor pengamatan berukuran $\mathrm{nx} 1$

$\alpha_{t}$ : nilai error pada waktu ke- $t$

$p$ : orde AR

$d$ : orde differencing

$q$ : orde MA

$B$ : operator back shift

$D(B)$ : operator differencing

$\phi_{p}(B)$ : matriks parameter vektor autoregressive ordo ke-p berukuran $n \times n$

$\theta_{q}(B):$ matriks parameter vektor moving average ordo ke- q berukuran $n \times n$.

\subsection{Inflasi}

Inflasi merupakan seluruh kenaikan harga dalam perekonomian. Bank Indonesia mengartikan inflasi sebagai suatu peningkatan harga-harga secara umum dan terus menerus. Badan Pusat Statistik menggunakan Indeks Harga Konsumen (IHK) sebagai indikator penghitungan inflasi, dimana inflasi merupakan persentase perubahan IHK pada suatu waktu (Mankiw, 2007).

\subsection{Suku Bunga}

Suku bunga di Indonesia merupakansuku bunga kebijakan yang mencerminkan sikap kebijakan moneter yang ditetapkan oleh Bank Indonesia dan diumumkan kepada publik. Suku Bunga Indonesia (SBI) adalahsuku bunga yang dihasilkan dari faktorfaktor seperti jumlah dan tingkat suku bunga penawaran selama pelelangan SBI, periode SBI yang ditawarkan, likuid itas pasar, dan lain sebagainya (BI, 2016).

\section{Metode Penelitian}

Pengolahan data dilakukan dengan menggunakan bantuan softwarestatistika. Data yang digunakan dalam penelitian ini adalah data sekunder dari website resmi Bank Sentral Republik Indonesia, yaitu data bulanan laju inflasi $\left(Y_{1}\right)$ dan suku bunga Indonesia $\left(Y_{2}\right)$ dari bulanan, mu lai dari bulan Januari 2009 sampai Desember 2016. Data penelitian ini digunakan data dari tahun 2009-2016 untuk menentukan model yang sesuai (in sample), sedangkan data pada tahun 2017 digunakan untuk validasi hasil ramalan (out sample).

Langkah-langkah penelitian, antara lain: (1) menguji stasioneritas, (2) mengidentifikasi model VARIMAmelalui penentuan lag yang memuat nilai AIC terkecil, (3) menguji signifikansi parameter dan 
menguji residual, (4) pemeriksaan asumsi residual, dan (5) pera malan.

\section{Hasil dan Pembahasan}

Pada Gambar 1 dan Gambar 2 berikut, diberikan time series plot untuk masing-masing data laju inflasi dan suku bunga di Indonesia tahun 2009 sampai dengan 2016.

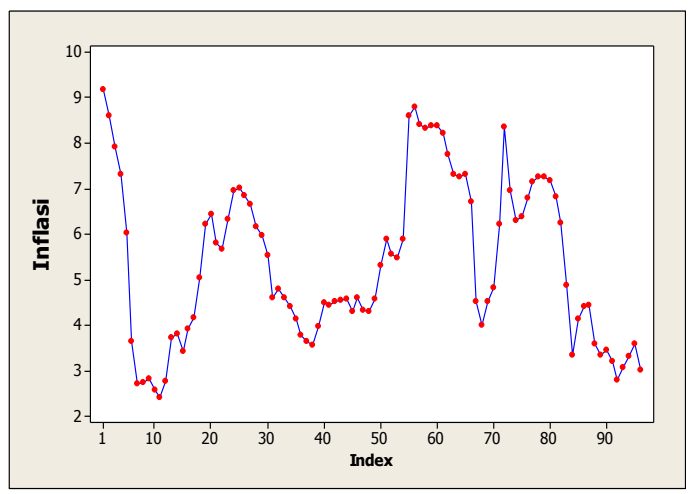

Gambar 1 - Time Series Plot Data Laju Inflasi

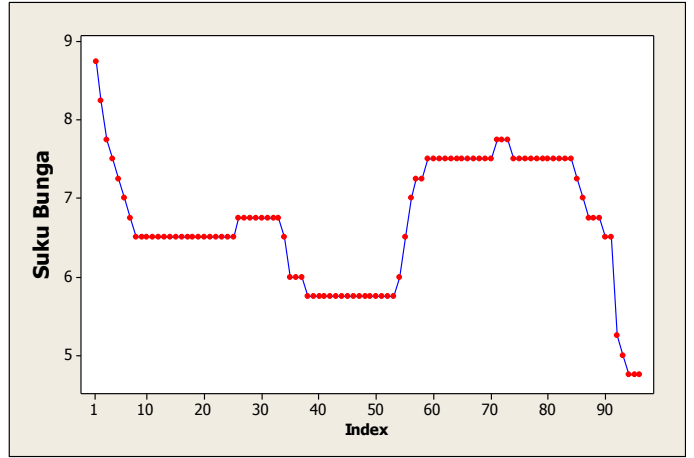

Gambar 2 - Time Series Plot Data Suku Bunga

Berdasarkan Gambar 1 dan Gambar 2, kedua time series plotmenunjukkan bahwa pola data Inflasi dan suku bunga menunjukkan adanya kecenderungan naik/turun. Suatu proses dikatakan stasioner, apabila dalam proses tersebut tidak terdapat perubahan kecenderungan, baik dalam rata-rata maupun variansi. Untuk memperkuat hal ini, dapat digunakan autocorrelation function (ACF) plotuntuk masingmasing data laju inflasi dan suku bunga di Indonesia, seperti yang tertera pada Gambar 3 dan Gambar 4 berikut.

Gambar 3 dan Gambar 4 menunjukkan bahwa nilai autokorelasi turun secara lambat (dies down) seiring dengan lag yang semakin besar. Hal ini mengindikasikan bahwa data yang dimiliki belum stasioner.

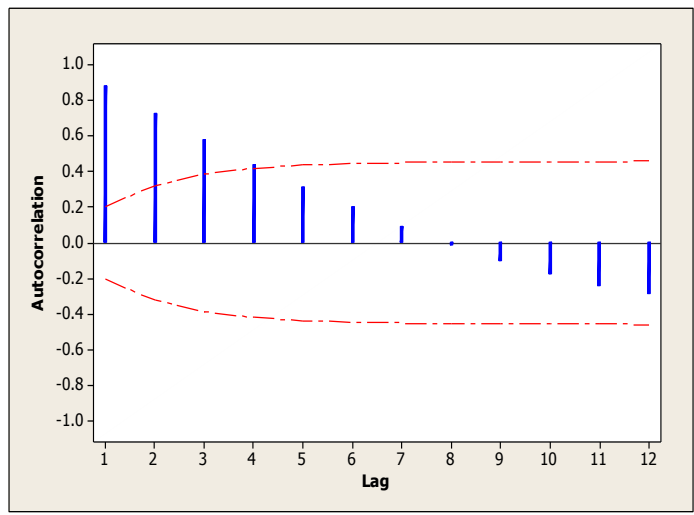

Gambar 3 - Plot ACF Data Laju Infl asi

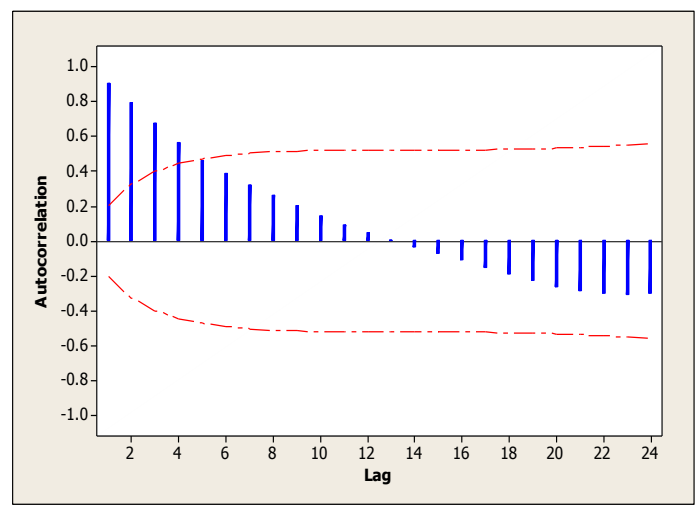

Gambar 4 - Plot ACF Data Suku B unga

Selanjutnya, digunakan Box-Cox plot untuk mengecek kestasioneran data dalam varian.Berdasarkan pengujian yang dilakukan, diperoleh nilai parameter transformasi lambda $(\lambda)$ sebesar masing-masing sebesar 0,5 untuk data laju inflasi dan suku bunga. Hal ini mengindikasikan keadaan data yang belum stasioner dalam varian. Oleh karena itu, perlu dilakukan proses transformasi Box-Coxdalam rangka menstasionerkan data tersebut dengan menggunakan kriteria pada Tabel 1. Hasil transformasi menunjukkan nilai $\lambda=1$ yang berarti bahwa data laju inflasi dan suku bunga telah stasioner dalam varian.

Data yang telah stasioner dalam varian tersebut di differencing untuk memperoleh data yang stasioner dalam rata-ratanya. Setelah melakukan 2 (dua) kali differencing pada masing-masing data inflasi dan suku bunga, diperoleh data yang stasioner dalam varian maupun rata-ratanya. Hal ini tentunya diperkuat pula oleh ACF plot yang tidak lagi turun secara lambat (dies down), namun cut-off setelah lag tertentu. 


\subsection{Identifikasi Model VARIMA}

Identifikasi vektor model time series pada prinsipnya sama dengan identifikasi model time seriesdengan variabel tunggal. Untuk sebanyak $n$ data pengamatan $\left(Y_{1}, Y_{2}, \ldots ., Y_{n}\right)$, maka identifikasi vektor model time series didasarkan pada pola matriks fungsi autokorelasi (Matrix Autocorrelation Function/ MACF) dan matriks fungsi autokorelasi parsial (Matrix Partial Autocorrelation Function/ MPACF).

Pada Tabel 2 dan Tabel 3, tanda (+) mengindikasikan nilai korelasi yang signifikan, yaitu nilai korelasi > 2 kali nilai standar error; tanda (-) mengindikasikan nilai korelasi yang signifikan, yaitu nilai korelasi $<-2$ kali nilai standar error; dan tanda (.) mengindikasikan nilai korelasi yang tidak signifikan, yaitu nilai korelasi berada dalam selang 2 kali nilai standar error.Pada Tabel 2 berikut, diberikan MACF untuk masing-masing data laju inflasi $\left(Y_{1}\right)$ dan suku bunga $\left(Y_{2}\right)$.

Tabel 2 - Matrix Autocorrelation Function

\begin{tabular}{|c|c|c|}
\hline \multirow{2}{*}{ Lag } & \multicolumn{2}{|c|}{ Variabel } \\
\hline & Inflasi $\left(Y_{1}\right)$ & Suku Bunga $\left(Y_{2}\right)$ \\
\hline 0 & + &.+ \\
\hline 1 & .• & .- \\
\hline 2 & -. & .• \\
\hline 3 & .. & .. \\
\hline 4 & .. & .. \\
\hline 5 & .. & .. \\
\hline 6 & .. & .. \\
\hline 7 & .. & .. \\
\hline 8 & .. & .. \\
\hline 9 & .. & .. \\
\hline 10 & .. & .• \\
\hline 11 & .. & .• \\
\hline 12 & -. & .. \\
\hline
\end{tabular}

Berdasarkan Tabel 2, dapat dilihat bahwa plot MACF menunjukkan cut off setelah lag2, yang menyatakan bahwa plot data sudah stasioner dan diperoleh orde model Moving Average MA(2). Selanjutnya, pada Tabel 3 diberikan MPACF untuk data laju inflasi $\left(Y_{1}\right)$ dan suku bunga $\left(Y_{2}\right)$.

Tabel 3 menunjukkan bahwa plot MPACF menunjukkan cut off setelah lag 4, yang menyatakan bahwa plot data sudah stasioner dan diperoleh orde model AutoregressiveAR(4). Oleh karenanya, dapat disimpulkan bahwa model sementara yang diperoleh adalah 14 model kombinasi kemungkinan dari orde $A R$, yaitu $p=0,1,2,3,4$, dan kemungkinan orde
$M A$, yaitu $q=0,1,2$, dengan orde differencing $d=2$

Tabel 3 - Matrix Partial Autocorrelation Function

\begin{tabular}{ccc}
\hline \multirow{2}{*}{ ag } & \multicolumn{2}{c}{ Variabel } \\
\cline { 2 - 3 } & Inflasi $\left(Y_{1}\right)$ & Suku Bunga $\left(Y_{2}\right)$ \\
\hline 1 &.. &.- \\
2 &.- &.. \\
3 &.- &.. \\
4 &.. &.- \\
5 &.. &.. \\
6 &.. &.. \\
7 &.. &.. \\
8 &.. &.. \\
9 &.. &.. \\
10 &.. &.. \\
11 &.. &.. \\
12 &.- &
\end{tabular}

Model sementara yang dapat dibentuk antara lain model VARIMA (4,2,2), VARIMA $(4,2,1)$, VARIMA $(4,2,0), \operatorname{VARIMA}(3,2,2), \operatorname{VARIMA}(3,2,1)$, VARIMA $(3,2,0), \operatorname{VARIMA}(2,2,2), \operatorname{VARIMA}(2,2,1)$, VARIMA $(2,2,0)$, VARIMA $(1,2,2)$, VARIMA $(1,2,1)$, VARIMA $(1,2,0)$, VARIMA (0,2,2), dan VARIMA $(0,2,1)$. Setelah dilakukan estimasi parameter dari 14 model sementara, diperoleh nilai AIC terendah berdasarkan Persamaan (6) berada pada model $\operatorname{VARIMA}(0,2,2)$, dengan nilai $A I C=-4,2565$.

Estimasi dengan MLE menghasilkan estimator untuk parameter model VARIMA sebagai berikut.

$$
\hat{\theta}=\left(X_{t}{ }^{\prime} X_{t}\right)^{-1} X_{t}{ }^{\prime} Y_{t}, \quad t=1,2, \cdots, 92
$$

dengan $Y_{t}=\left[Y_{1, t}, Y_{2, t}\right]^{\prime} \quad$ dan $\left(Y_{1, t}, Y_{2, t}\right)$ masingmasing merupakan data laju inflasi dan suku bunga. Tabel 4 menunjukkan hasil estimasi parameter dan nilai peluang ( $p$-value) untuk pengujian signifikansi model yang diperoleh.

Tabel 4-Estimasi Parameter Model VARIMA(0,2,2) Data Laju Inflasi $\left(Y_{1}\right)$ dan Suku Bunga $\left(Y_{2}\right)$

\begin{tabular}{crrl}
\hline Parameter & $\begin{array}{c}\text { Nilai } \\
\text { Es timasi }\end{array}$ & p-value & Keterangan \\
\hline Variabel $Y_{1}$ & & & \\
\hline$\theta_{0}$ & 0,0034 & 0,0029 & Signifikan \\
$\theta_{11}^{(1)}$ & 0,6626 & $2 \times 10^{-16}$ & Signifikan \\
$\theta_{12}^{(1)}$ & $-0,0519$ & 0,0348 & Signifikan
\end{tabular}




\begin{tabular}{|c|c|c|c|}
\hline Parameter & $\begin{array}{c}\text { Nilai } \\
\text { Es timasi }\end{array}$ & $p$-value & Keterangan \\
\hline$\theta_{11}^{(2)}$ & 0,5119 & $2 \times 10^{-16}$ & Signifikan \\
\hline$\theta_{12}^{(2)}$ & $-0,0502$ & ,0955 & $\begin{array}{c}\text { Tidak } \\
\text { Signifikan } \\
\end{array}$ \\
\hline \multicolumn{4}{|l|}{ Variabel $Y_{2}$} \\
\hline$\theta_{0}$ & $-0,0002$ & 0,9511 & $\begin{array}{c}\text { Tidak } \\
\text { Signifikan }\end{array}$ \\
\hline$\theta_{21}^{(1)}$ & $-0,1250$ & $2 \times 10^{-16}$ & Signifikan \\
\hline$\theta_{22}^{(1)}$ & 0,6930 & $2 \times 10^{-16}$ & Signifikan \\
\hline$\theta_{21}^{(2)}$ & $-0,0079$ & 0,6071 & $\begin{array}{c}\text { Tidak } \\
\text { Signifikan }\end{array}$ \\
\hline$\theta_{22}^{(2)}$ & 0,0475 & 0,2678 & $\begin{array}{c}\text { Tidak } \\
\text { Sigifikan }\end{array}$ \\
\hline
\end{tabular}

Model VARIMA $(0,2,2)$ memiliki 10 parameter. Berdasarkan Tabel 4, nilai $p$-value masing-masing nilai estimasi parameter menunjukkan bahwa tidak semua parameter memiliki pengaruh yang signifikan terhadap model. Untuk mengatasi adanya parameter yang tidak signifikan tersebut, maka dilakukan perbaikan terhadap estimasi parameter model.

Tabel 5 - Estimasi Parameter Model VARIMA(0,2,2)

Data Laju Inflasi $\left(Y_{1}\right)$ dan Suku Bunga $\left(Y_{2}\right)$ Setelah Perbaikan

\begin{tabular}{crrc}
\hline Parameter & $\begin{array}{c}\text { Nilai } \\
\text { Es timasi }\end{array}$ & p-value & Keterangan \\
\hline Variabel $Y_{1}$ & & & \\
\hline$\theta_{0}$ & 0,0049 & 0,0477 & Signifikan \\
$\theta_{11}^{(1)}$ & 0,6627 & $2 \times 10^{-16}$ & Signifikan \\
$\theta_{12}^{(1)}$ & 0,6770 & $2 \times 10^{-16}$ & Signifikan \\
$\theta_{11}^{(2)}$ & 0,5123 & $2 \times 10^{-16}$ & Signifikan \\
$\theta_{12}^{(2)}$ & 0 & 0 & Signifikan \\
\hline Variabel $Y_{2}$ & & & \\
\hline$\theta_{0}$ & 0 & 0 & Signifikan \\
$\theta_{12}^{(1)}$ & $-0,1410$ & $4,1 \times 10^{-7}$ & Signifikan \\
$\theta_{22}^{(1)}$ & $-0,0499$ & 0,1121 & Tidak \\
$\theta_{12}^{(2)}$ & 0 & 0 & Signifikikan \\
$\theta_{22}^{(2)}$ & 0,0504 & 0,1230 & Signifikan \\
\hline
\end{tabular}

Tabel 5 menujukkan bahwa setelah dilakukan perbaikan pada estimasi parameter model, terlihat bahwa masih terdapat estimasi parameter yang tidak signifikan pada variabel $Y_{2}$ dengan tingkat signifikansi 5\%. Keseluruhan estimasi parameter tersebut dapat dikatakan signifikan pada tingkat signifikansi yang lebih kecil. Hal ini menunjukkan bahwa parameter tersebut memiliki pengaruh yang sangat kecil terhadap model.Berikut diberikan model $\operatorname{VARIMA}(0,2,2)$ yang diperoleh.

$$
\begin{aligned}
{\left[\begin{array}{l}
Y_{1, t} \\
Y_{2, t}
\end{array}\right] } & =\left[\begin{array}{c}
0,00489 \\
0
\end{array}\right]+\left[\begin{array}{l}
\alpha_{1, t} \\
\alpha_{2, t}
\end{array}\right] \\
& -\left[\begin{array}{cc}
0,6627 & 0,677 \\
-0.141 & -0,0499
\end{array}\right]\left[\begin{array}{l}
\alpha_{1, t-1} \\
\alpha_{2, t-1}
\end{array}\right] \\
& -\left[\begin{array}{cc}
0,5123 & 0 \\
0 & 0,0504
\end{array}\right]\left[\begin{array}{l}
\alpha_{1, t-2} \\
\alpha_{2, t-2}
\end{array}\right]
\end{aligned}
$$

Berdasarkan Tabel 5 dan model pada Persamaan (11), estimasi parameter model setelah dilakukannyaperbaikan, diketahui bahwa variabel inflasi pada waktu ke- $t$ dipengaruhi secara nyata pada tingkat signifikansi 5\% oleh error model variabel inflasi dan variabel suku bunga, masingmasing pada waktu ke- $(t-1)$ dan $(t-2)$. Selanjutnya, variabel suku bunga pada waktu ke- $t$ dipengaruhi secara nyata pada tingkat signifikansi hingga 13\% oleh error model variabel inflasi dan variabel suku bunga, masing-masing pada waktuke$(t-1)$ dan $(t-2)$.

Langkah selanjutnya yang dilakukan adalah melakukan pengujian residual model. Pengujian residual bersifat white noisemenggunakan statistik uji Ljung Box-Piercepada Persamaan (7), dengan tingkat signifikansi $5 \%, \quad$ memberikan nilai $Q_{k}(m)<\chi_{\alpha, k-1}^{2}(3,84)$. Oleh karenanya, model $\operatorname{VARIMA}(0,2,2)$ me miliki residual yang white noise.

Selanjutnya,pengujian residual berdistribusi normalmenggunakan statistik uji KolmogorovSmirnovpada Persamaan (8), dengan tingkat signifikansi $5 \%, \quad$ memberikan nilai $D(0,161)>D_{(1-\alpha, n)}(0,0995)$. Oleh karenanya, dapat dikatakan bahwa residual tidak berdistribusi normal. Hal ini terjadi karena terdapat pencilan pada data, sehingga perlu untuk diatasi dengan melakukan tranformasi data. Lebih jauh lagi, estimasi parameter dalam model dilakukan menggunakan metode maximum likelihood yang tidak me mbutuhkan asumsi residual berdistribusi normal, sehingga tidak terpenuhinya asumsi residual berdistribusi normal 
tidak berpengaruh terhadap hasil peramalan yang diperoleh.

Peramalan data laju inflasi dan suku bunga berdasarkan model $\operatorname{VARIMA}(0,2,2)$ dilakukan dengan berdasarkan pada Persamaan (11). Data yang diramalkan merupakan data 12 bulan ke depan, yaitu data bulan Januari 2017 sampai dengan Desember 2017 untuk masing-masing data inflasi dan data suku bunga di Indonesia. Hasil peramalan data inflasi dan data suku bunga di Indonesia tertera pada Tabel 6 sebagai berikut.

Tabel 6 - Hasil Peramal an Data

\begin{tabular}{ccccc}
\hline \multirow{2}{*}{$\begin{array}{c}\text { Bulan } \\
\text { ke- }\end{array}$} & \multicolumn{2}{c}{ Laju Inflasi $\left(Y_{1}\right)$} & \multicolumn{2}{c}{ Suku Bunga $\left(Y_{2}\right)$} \\
\cline { 2 - 5 } & $\begin{array}{c}\text { Data } \\
\text { Aktual }\end{array}$ & $\begin{array}{c}\text { Data } \\
\text { Prediksi }\end{array}$ & $\begin{array}{c}\text { Data } \\
\text { Aktual }\end{array}$ & $\begin{array}{c}\text { Data } \\
\text { Prediksi }\end{array}$ \\
\hline 1 & 3,49 & 3,194 & 4,75 & 4,553 \\
2 & 3,83 & 3,765 & 4,75 & 4,776 \\
3 & 3,61 & 3,835 & 4,75 & 4,750 \\
4 & 4,17 & 3,615 & 4,75 & 4,750 \\
5 & 4,33 & 4,175 & 4,75 & 4,750 \\
6 & 4,37 & 4,335 & 4,75 & 4,750 \\
7 & 3,88 & 4,375 & 4,75 & 4,750 \\
8 & 3,82 & 3,885 & 5,75 & 4,750 \\
9 & 3,72 & 3,825 & 5,75 & 5,750 \\
10 & 3,58 & 3,725 & 5,75 & 5,750 \\
11 & 3,30 & 3,585 & 5,75 & 5,750 \\
12 & 3,61 & 3,305 & 5,75 & 5,750 \\
\hline
\end{tabular}

Berdasarkan hasil peramalan pada Tabel 6, diberikan plot antara data asli (aktual) dengan data prediksi, pada Gambar 5 untuk data laju inflasi $\left(Y_{1}\right)$ dan pada Gambar 6 untuk data suku bunga $\left(Y_{2}\right)$.

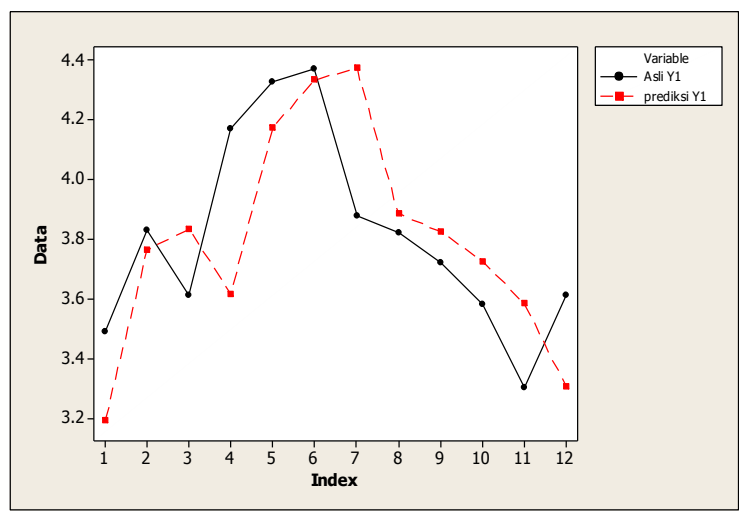

Gambar 5 -Plot Peramal an Data Laju Inl fasi

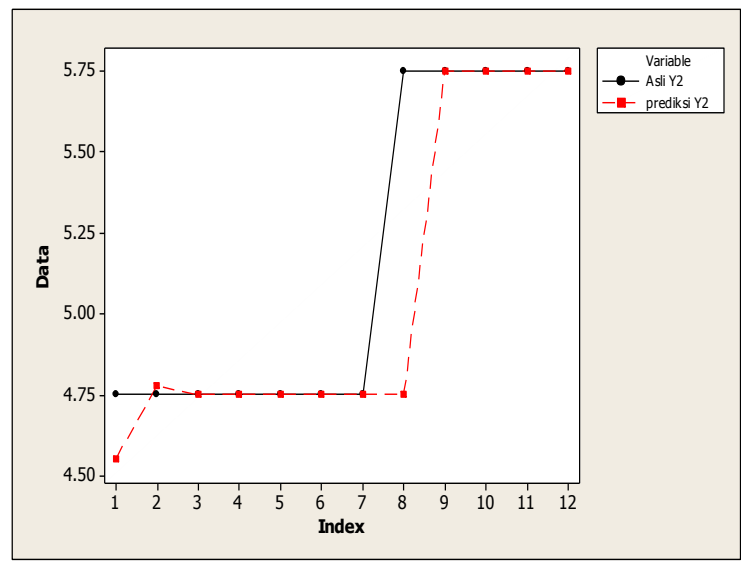

Gambar 6 - Plot Peramalan Data Suku Bunga

Selanjutnya, untuk mengetahui tingkat ketepatan hasil peramalan, maka dapat dilakukan perbandingan data hasil peramalan dengan data as li (aktual), seperti yang tertera pada Tabel 6, serta divisualisasikan pada Gambar 5 dan Gambar 6. Hasil peramalan dikatakan baik apabila hasil peramalan tidak berbeda jauh dengan data asli, atau nilai kesalahan peramalan yang merupakan selisih antara hasil peramalan dengan data asli (aktual) relatif kecil, yang dapat dilihat dari nilai Mean Absolut Percentage Error(MAPE)pada Persamaan (9).

Tabel 7 - Pengujian Ketepatan Peramalan

\begin{tabular}{cc}
\hline \multicolumn{2}{c}{ Nilai MAPE } \\
\hline Laju Inflasi $\left(Y_{1}\right)$ & Suku Bunga $\left(Y_{2}\right)$ \\
\hline $6,04 \%$ & $1,84 \%$ \\
\hline
\end{tabular}

Berdasarkan nilai MAPE yang diperoleh, diketahui bahwa peramalan data laju inflasi dan suku bunga di Indonesia menggunakan model $\operatorname{VARIMA}(0,2,2)$ memberikan hasil peramalan yang sangat baik.

\section{PENUTUP}

Berdasarkan penelitian yang telah dilakukan, dapat disimpulkan bahwa dan pembahasan dapat disimpulkan bahwa error model variabel inflasi dan variabel suku bunga, masing-masing pada waktu ke$(t-1)$ dan $(t-2)$ memberikan pengaruh yang nyata pada data laju inflasi dan suku bunga di Indonesia. Selanjutnya, model $\operatorname{VARIMA}(0,2,2)$ yang diperoleh menunjukkan hasil peramalan dengan nilai ketepatan peramalan yang sangat baik, untuk masingmasing data laju inflasi dan suku bunga di Indonesia. 


\section{DAFTAR PUSTAKA}

Bain L.J.dan Engelhardt, M.(1992). Introduction to Probability and Mathematical Statistics. California: Du xbury Press.

Bank Indonesia (BI). (2016).Informasi Dasar Suku Bunga. http://www.bi.go.id/. Diakses pada Januari 2019.

Draper, N. R. dan Smith, H. (1998)Applied Regression Analysis $3^{\text {rd }}$ Edition. United States of America: John Wiley and Sons.

Hermayani, Nohe, D.A., dan Fathurahman, M. (2014). Mengatasi Heteroskedastisitas pada Model ARIMA Menggunakan ARCHGARCH (Studi Kasus: IHK Provinsi Kalimantan Timur Tahun 2005-2012).Jurnal Eksponensial, 5(1), $73-81$.

Makridakis, S., Wheelwright, S., dan McGee, V. (1999). Metode dan Aplikasi Peramalan, Jilid 1 Edisi Kedua Terjemahan Ir. Untung S. Andriyanto dan Ir. Abdul Basith.Jakarta: Penerbit Erlangga.

Mankiw, N. G. (2007). Teori Makroekonomi Edisi Keenam. Jakarta: Erlangga.

Matjik,A.A. danSumertajaya, I. M. (2011).Sidik Variabel Ganda dengan Menggunakan SAS. Bogor: IPB PRESS.

Rinaldy, R. (2016). Analisis Peramalan Data Runtun Waktu Menggunakan Vector Autoregressive Integrated Moving Average (VARIMA), SkripsiJurusan Matematika Fakultas Matematika dan Ilmu Pengetahuan Alam, Universitas Lampung .

Sukirno, S. (2008). Teori Pengantar Ekonomi Makro.Jakarta: Raja Grafindo Persada.

Sunariyah. (2014). Pengantar Pengetahuan Pasar Modal Edisi Kelima.Bandung: CV Alfabeta.

Wei, W. W. (2006). Time Series Analysis: Univariate and Multivariate Method.USA: Pearson Educations.

Zainun, N.Y. dan Majid,M.Z.A. (2003). Low Cost House Demand Predictor.Malaysia: Universitas Teknologi Malaysia. 